\title{
Pituitary ACTH cells in female rats after neonatal treatment with SRIH-14
}

\author{
Verica Milošević, Nataša Nestorović, Milica Terzić, Nataša Ristić, \\ Vladimir Ajdžanović, Svetlana Trifunović, Milka Sekulić
}

Institute for Biological Research, "Siniša Stanković", University of Belgrade, Serbia

\begin{abstract}
The prolonged effects of neonatal SRIH-14 treatment on pituitary ACTH cells were investigated. Neonatal female rats were injected subcutaneously with SRIH $\left(20 \mu \mathrm{g} / 100 \mathrm{~g}\right.$ b.w.) every 12 hours for five consecutive days ( $3^{\text {rd }} 7^{\text {th }}$ day of life). Groups of rats were then killed at the juvenile ( $16^{\text {th }}$ day), peripubertal ( $38^{\text {th }}$ day) or adult ( $80^{\text {th }}$ day) stage. ACTH cells were visualized using the peroxidase-antiperoxidase immunocytochemical procedure. Morphometry and stereology were used to evaluate the ACTH-immunoreactive cell volume and volume density. The histological and immunocytochemical characteristics of ACTH cells in neonatally treated females were changed in all examined periods. Thus, SRIH-14 induced significant $(\mathrm{p}<0.05)$ decreases of ACTH cell volume in juvenile, peripubertal and adult rats by $26 \%, 39 \%$ and $14 \%$, respectively, in comparison to the corresponding controls. The volume density of ACTH cells was also diminished (by $31 \%$; $<<0.05$ ) at the juvenile stage in comparison with the corresponding controls. In peripubertal and adult rats, the volume densities of ACTH cells were somewhat lower ( $17 \%$ and $14 \%$, respectively), but the decreases did not reach statistical significance. These findings suggest that neonatal treatment with SRIH-14 exerts a marked prolonged inhibitory effect on ACTH cell morphology extending to the adult period of life.
\end{abstract}

Key words: female rats, somatostatin, $\mathrm{ACTH}$ cells, development, immunocytochemistry

\section{Introduction}

Somatostatin (somatotropin release-inhibiting hormone, SRIH) is a hypothalamic hormone that was originally characterized as a potent inhibitor of growth hormone $(\mathrm{GH})$ secretion [1]. In the pituitary, SRIH also blocks the release of other hormones, such as thyrotrophin (TSH) [2] prolactin (PRL) [3] and gonadotrophins $[4,5]$. At the periphery, SRIH is a modulator of endocrine and exocrine functions and regulates differentiation and proliferation of normal and tumor cells [6,7]. Within the nervous system, SRIH acts as a neuromodulator with physiological effects on neuroendocrine, motor and cognitive functions $[8,9]$.

The hypothalamic-pituitary-adrenal (HPA) axis is an important control system and dynamic interface for multiple physiological systems. Biochemically interconnected, it generates rhythmic hormone secretion. The respective hormones, corticotrophin releasing hor-

Correspondence: V. Milošević, N. Nestorović, Institute for Biological Research, "Siniša Stanković", University of Belgrade, 11060 Belgrade, Serbia

e-mail:dimi@ibiss.bg.ac.rs; rnata@ibiss.bg.ac.rs. mone $(\mathrm{CRH})$, adrenocorticotropic hormone (ACTH) and principle glucocorticosteroids (CORT; i.e. cortisol in humans, corticosterone in rats), modulate their own secretion through feed forward and feedback mechanisms within the HPA axis and exert physiological effects in target organs outside the HPA axis [10].

Corticotrophs (ACTH cells) are basophilic cells, which produce proopiomelanocortin (POMC) and its derivatives including ACTH, melanotropin (MSH) and lipotropin (LPH). They represent approximately 15 to $20 \%$ of adenohypophysial cells [11]. ACTH release from the anterior pituitary is regulated by a variety of hormones and neuropeptides, by both cAMP dependent and cAMP independent mechanisms [12]. SRIH or its synthetic analogs can reduce circulating ACTH and glucocorticoid levels in rats and humans in vivo $[13,14]$.

We have previously shown that multiple neonatal treatment with SRIH-14 inhibited ACTH cells in the pituitaries of neonatal female rats [15]. The aim of this study was to examine whether this treatment has prolonged effects on the morphological characteristics of pituitary ACTH cells of female rats extending to juvenile, peripubertal and adult periods of life. 


\section{Materials and methods}

Experimental animals. Time-mated Wistar rats were housed individually and maintained in a controlled environment $(12 \mathrm{~h}$ light: $12 \mathrm{~h}$ dark; $22 \pm 2^{\circ} \mathrm{C}$ ), with feed food ("Subotica" Veterinarski Zavod, Subotica, Serbia) and water freely available. Neonatal $\left(3^{\text {rd }}-7^{\text {th }}\right.$ day of life) female rats were injected subcutaneously twice a day (8 AM and $8 \mathrm{PM}$ ) with $20 \mu \mathrm{g}$ of SRIH-14 (S9129, Sigma, St. Louis, Mo., USA) per $100 \mathrm{~g}$ b.w. for five consecutive days. The dose regimen selected for SRIH-14 was based on that of Rebuffat et al. [16] and modified for administration every 12 $\mathrm{h}$ instead of every $8 \mathrm{~h}$. Control female rats received subcutaneously the equivalent volume of saline by the same schedule. Groups of five animals were killed at $8 \mathrm{AM}$ at the juvenile $\left(16^{\text {th }}\right.$ day), peripubertal ( $38^{\text {th }}$ day) or adult ( $80^{\text {th }}$ day) period of life. The experimental protocols were approved by the Local Animal Care Committee and conformed to the recommendations given in the "Guide for the Care and Use of Laboratory Animals" (1996, National Academy Press, Washington D.C.).

Light microscopy and immunocytochemistry. The pituitaries were removed immediately after sacrifice and fixed in Bouin's solution for $48 \mathrm{~h}$ at room temperature. After dehydration in an ethanol gradient, organs were embedded in paraffin. Series of seven sections $(5 \mu \mathrm{m})$ of the pituitary cut through three tissue levels (dorsal, middle and ventral portion) of the pars distalis were used for immunostaining. For localization of ACTH cells the peroxidase-antiperoxidase method was used [17]. After deparaffinization and rehydration of sections, endogenous peroxidase activity was blocked by incubation in methanol containing $0.3 \%$ $\mathrm{H}_{2} \mathrm{O}_{2}$ for $15 \mathrm{~min}$ at room temperature, followed by rinsing in 0.1 $\mathrm{M}$ phosphate buffered saline (PBS; $\mathrm{pH}$ 7.4) for $5 \mathrm{~min}$. The nonspecific background staining was reduced by incubation for 45 min with non-immune serum, i.e. normal porcine serum diluted 1:10 with PBS. The sections were then incubated overnight with primary antibodies $(1: 1000 \mathrm{v} / \mathrm{v}$ rACTH antisera National Hormone \& Peptide Program, Harbor-Ucla Medical Center, Torrance, CA 90509) for $1 \mathrm{~h}$ at room temperature. Subsequent to a 5 minute rinse in PBS, the sections were incubated with secondary antibody (1:500 swine-anti-rabbit IgG, $45 \mathrm{~min}$; DAKO A/S, Glostrup, Denmark), rinsed for 5 min in PBS, incubated with rabbit-antiperoxidase serum (1:100; 45 min; DAKO A/S, Glostrup, Denmark) and again rinsed in PBS. The antigen-antibody complex was visualized by incubating the sections with chromogen substrate, $0.05 \%$ 3,3-diaminobenzidine (DAB; Serva, Heidelberg, Germany) and $0.03 \% \mathrm{H}_{2} \mathrm{O}_{2}$. The incubated sections were counterstained with hematoxylin. Control sections were incubated with normal porcine serum without primary antisera. Digital images were made on a DM RB photomicroscope (Leica, Wetzlar, Germany) with a JVCTK 1280E video camera (Leica) for the acquisition and analysis of the images.

Morphometry. The volume densities $\left(\mathrm{V}_{\mathrm{V}}\right)$ of the nuclei and the cytoplasm of ACTH-immuno-reactive cells, as well as numerical density $(\mathrm{Na})$ of their nuclei per $\mu \mathrm{m}^{3}$ were measured using 50 test areas of the pituitary gland at a magnification of X 1000, using the multipurpose test system $\mathrm{M}_{42}$ [18]. The number of nuclei in immunoreactive ACTH-cells per $\mathrm{mm}^{3}$ was estimated using the formula of Weibel and Gomez [19] according to Weibel [18]. Since rat ACTH cells are mononuclear, the numerical density of the nuclei $\left(\mathrm{N}_{\mathrm{V}}\right)$ corresponds to the number of cells per $\mathrm{mm}^{3}$.

$$
\mathrm{N}_{\mathrm{V}}=(\mathrm{k} / \beta) \times\left(\mathrm{Na}^{3 / 2} / \mathrm{Vv}^{1 / 2}\right)
$$

On the basis of earlier karyometric studies [20], the shape coefficient $\beta$ of the pituitary cells was estimated to be 1.382 . It relates $\mathrm{N}_{\mathrm{V}}$ (number of cells counted per unit volume) to $\mathrm{Na}$ (number of cells counted per $\mathrm{mm}^{2}$ ) and $\mathrm{V}_{\mathrm{V}}$ (volume density) and
Table 1. Pituitary weight of control $(\mathrm{C})$ and female rats in different periods of life after neonatal SRIH-14 treatment. All values are given as means $\pm \mathrm{SD}$. ${ }^{\mathrm{a}} \mathrm{p}<0.05$ vs. controls of previous age group.

\begin{tabular}{|c|c|c|c|}
\hline Groups & Juvenile & Peripubertal & Adult \\
\hline C & $2.5 \pm 0.6$ & $5.6 \pm 0.9^{\mathrm{a}}$ & $11.8 \pm 2.3^{\mathrm{a}}$ \\
\hline \multirow{2}{*}{ SRIH-14 } & $2.4 \pm 0.9$ & $5.4 \pm 1.1$ & $11.6 \pm 1.3$ \\
& $(-4.0 \%)$ & $(-3.6 \%)$ & $(-1.7 \%)$ \\
\hline
\end{tabular}

depends on the axial ratio of the nuclei. The volume densities of ACTH-positive cells were expressed as percentages of total pituitary cells in $\mu \mathrm{m}^{3}$.

Statistical analysis. The data obtained for each group were averaged and the standard deviation was calculated. One-way analysis of variance (ANOVA), followed by the multiple range test of Duncan was used for comparisons of the differences between the groups. A probability value of $5 \%$ or less was considered statistically significant.

\section{Results \\ Pituitary weight}

Pituitary weight significantly increased from juvenile to pubertal (by 124\%) and from peripubertal to adult period of life (by 53\%) in control females. Multiple neonatal SRIH-14 administration did not significantly changed pituitary weight in any of examined periods of life (Table 1).

\section{Characteristics of immunopositive ACTH cells}

ACTH cells of the control females in all examined age groups were strongly immunocytochemically stained. They were polygonal in shape with prominent, often eccentrically located nuclei (Figs. 1a,b,c). ACTH-positive cells were positioned throughout the pituitary pars distalis and pars intermedia. It has been noted that ACTH cells of adult females are larger, with numerous longer cytoplasmatic extensions and more homogenously immunostained cytoplasm compared to those in immature animals (Fig. 1c). ACTH cells in the pituitaries of juvenile, peripubertal and adult females neonatally treated with SRIH-14 were smaller in size, and appeared less intensely immunostained than those in the corresponding controls (Fig. 1d,e,f).

\section{Morphometric parameters of ACTH cells of control females}

Stereological analysis showed that volume of ACTH cells did not differ from juvenile to peripubertal period of life in the pituitaries of control female rats. However, from peripubertal to adult period, a significant increase (by $23 \%$; $<<0.05$ ) was observed. The ACTH 


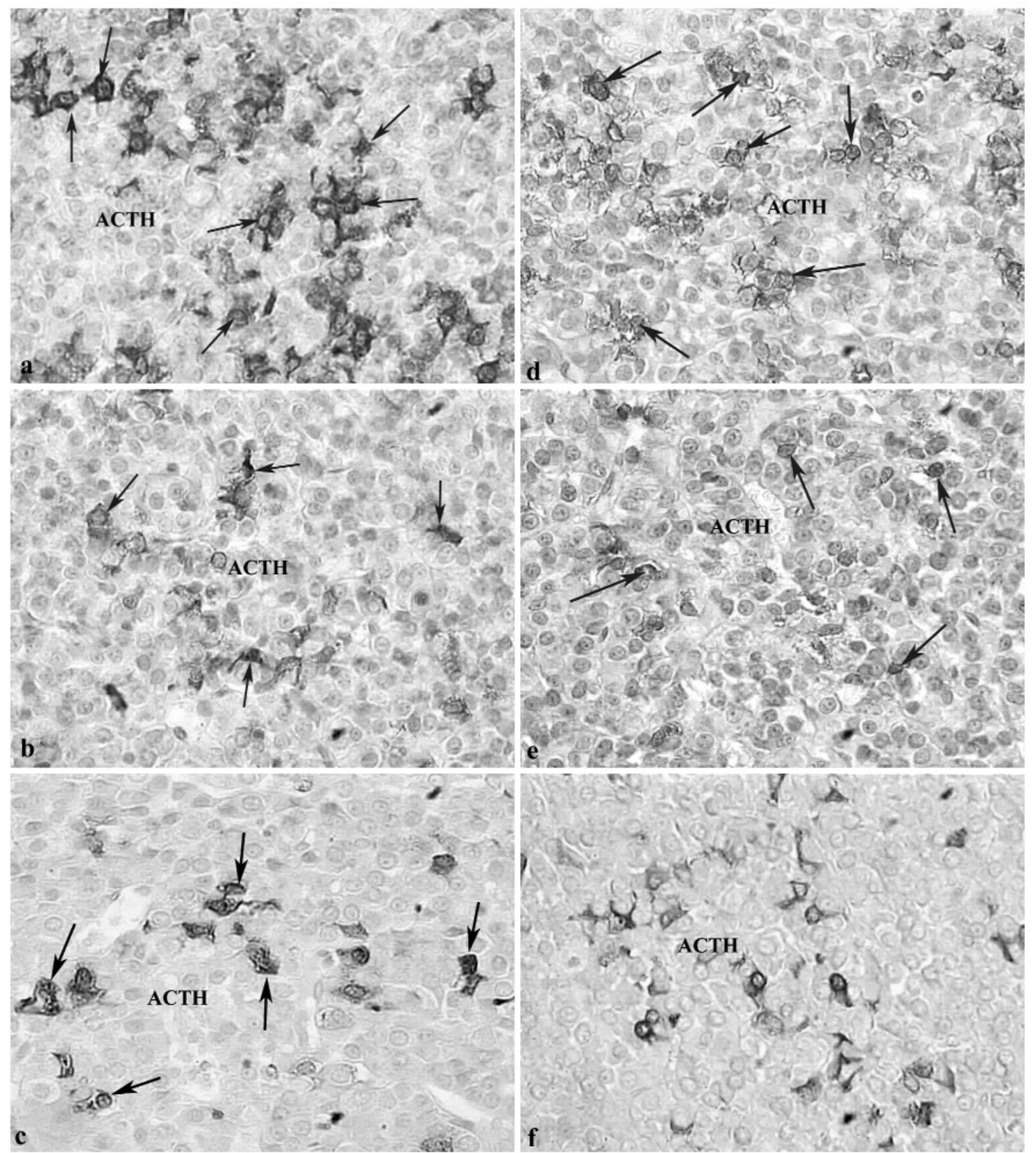

Fig. 1. Immunoreactive ACTH cells (arrows) in the pituitary pars distalis of female rats: control (a, b, c) and after neonatal SRIH-14 treatment (d, e, f); at juvenile (a, d), peripubertal (b, e) and adult (c, f) periods of life. (PAP, 1256×).

cell volume was significantly higher in adult than in juvenile period of life (by $25 \%$; $<<0.05$; Fig. 2a). The volume density of ACTH cells did not change from juvenile till adult period of life (Fig. 2b).

Volume of ACTH cells in the pituitaries of juvenile female rats neonatally treated with SRIH-14 was significantly decreased (by $26 \%$; p $<0.05$; Fig. 2a) compared to the controls. Their volume density, i.e. the percentage of ACTH cells per volume unit $\left(\mathrm{mm}^{3}\right)$ of total pituitary gland tissue, was also significantly lower (31\%; Fig. 2b).
In the pituitaries of peripubertal females neonatally treated with SRIH-14, the volume of ACTH cells was diminished (by $39 \%$; $<<0.05$ ) when compared to the corresponding controls (Fig. 2a). Their volume density was $17 \%$ lower, but this difference did not reach statistical significance (Fig. 2b).

Similarly, the volume of ACTH cells in the pituitaries of adult females neonatally treated with SRIH14 was decreased by $14 \%(p<0.05$. Fig. $2 a)$ and their volume density also tended to be lower $(14 \% ; p>0.05$; Fig. 2b). 

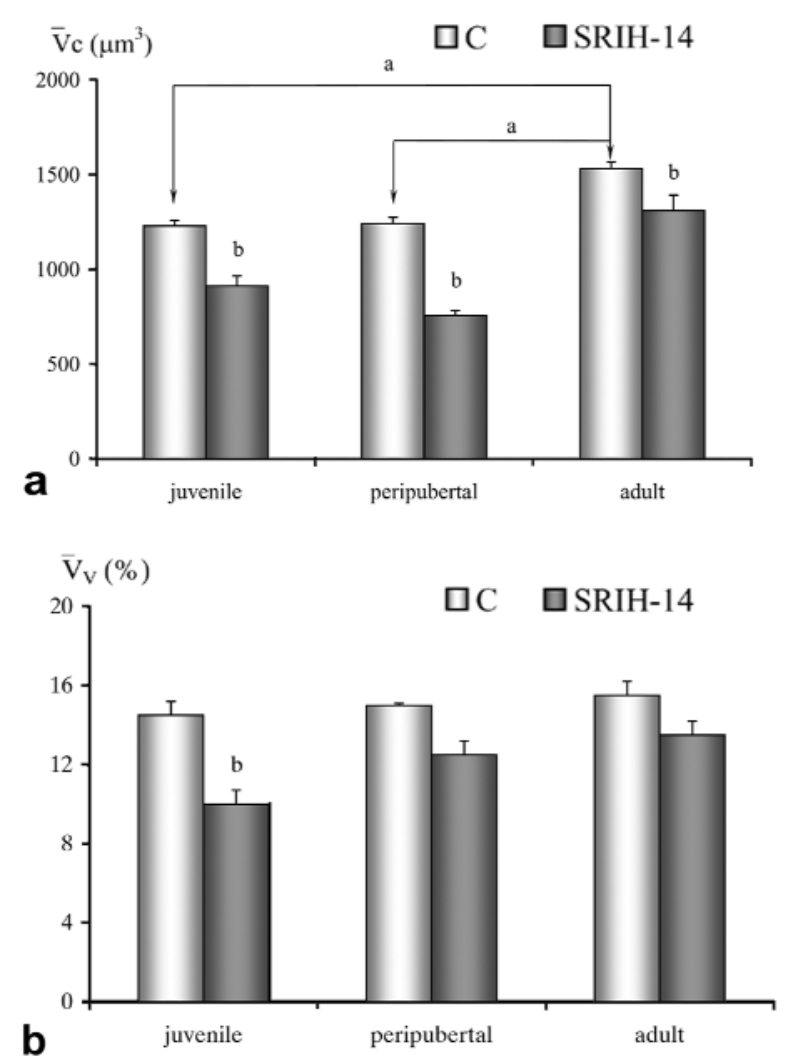

Fig. 2. a. The cellular volume $\left(\mathrm{Vc} ; \mu \mathrm{m}^{3}\right)$ of $\mathrm{ACTH}$-immunopositive cells of control (C) and experimental female rats after neonatal SRIH-14 treatment; $b$. volume density $\left(\mathrm{V}_{\mathrm{V}}\right)$ of immunoreactive ACTH cells expressed as a percentage (\%) of total adenohypophyseal cell volume in control (C) and experimental female rats after neonatal SRIH-14 treatment. All values are given as means \pm $\mathrm{SD} ; \mathrm{n}=5$ animals per group; ${ }^{\mathrm{p}}<0.05$ between controls of different age, ${ }^{b} p<0.05$ between SRIH-14 treated females and their corresponding controls.

\section{Discussion}

Multiple SRIH-14 doses applied in the neonatal period of life caused significant inhibition of ACTH cells when pituitaries were examined immediately after the treatment [15]. Prolonged effects of SRIH-14 on ACTH cells are largely unknown. In this study we have shown that changes in the volume, volume density and imunocytochemical appearance of ACTH cells caused by SRIH-14 in the neonatal period of life remained until adulthood.

Neonatally applied SRIH-14 did not cause the changes in pituitary weights in any of examined periods of life. These results are in accordance with our previous study [21]. Our earlier results [21] indicated that intracerebroventricular (i.c.v.) administration of SRIH-28 and the somatostatin analog, octreotide [22] to adult rat females exerts marked inhibitory effects on the morphometric and immunocytochemical parameters of ACTH cells and their function. Recently, Silva et al. [14] showed that the somatostatin analog, SOM230, significantly inhibited CRH-stimulated pituitary ACTH release in rats. Additionally, Luque et al. [23] reported that SRIH decreased POMC mRNA and $\mathrm{ACTH}$ release in the presence and absence of CRH in primary mouse pituitary cell cultures, indicating that SRIH can directly affect ACTH cells at the pituitary level. Studies on somatostatin [23] or sstr2 [24] knockout mice showed that ACTH levels were significantly increased in genetically altered compared to wild type animals, suggesting a physiological role of SRIH on ACTH secretion.

In rat pituitary cells, co-localization of all five somatostatin receptors (sstr) with ACTH expressing cells has been reported [25]. In another study, sst5 mRNA was found in $38 \%$ of normal corticotrophs, and sstr2 in only 3\% [26], whereas Mezey and coworkers [27] demonstrated sst2 in a large population and sstr5 in a small population of corticotrophs. Somatostatin influences ACTH secretion in pituitary cells in culture through inhibition of CRF-stimulated adenyl cyclase activity, and by preventing stimuluselicited calcium influx [28] over sstr2 and sstr5 receptor subtypes but not over sstr1, sstr3 or sstr4 [29]. Reed et al. [30] reported that the neonatal rat pituitary expresses the same complement of somatostatin receptors (sstr 1-5) as the adult pituitary. They also found that the expression of sst2 mRNA was age dependent. Levels of sst2 mRNA were low in pituitaries of 2-day-old animals, but thereafter rose progressively until adulthood. However, pituitaries of neonatal animals expressed sst 1 , sst3, sst4, and sst5 mRNA with no significant ontogenic changes in expression of these subtypes. SRIH-14, used in our study, is known to bind to all five somatostatin receptors with high affinity [7], and therefore had the opportunity directly to affect ACTH cells in the neonatal period of life. There is also some evidence that SRIH could inhibit ACTH cells indirectly, through inhibition of CRH release from the hypothalamus [31,7].

In our earlier study, neonatally applied SRIH-14 led to a significant decrease of both, volume of $\mathrm{ACTH}$ cells and their volume density by $39 \%$ and $33 \%$, respectively [15] in the pituitaries of neonatal females. The decrease of these parameters sustained till the juvenile period of life, observed in this study. After SRIH-14 treatment, changes were noted in immunocytochemical features of ACTH cells in the pituitaries of juvenile females, as well. The cytoplasm was not uniformly stained, that is, immunolabeled granules were clustered in groups and separated by unstained regions. These results suggest an inhibitory effect of neonatal SRIH-14 treatment. In the peripubertal period the immunocytochemical appearance of ACTH cells was similar to that seen in the juvenile period. Togeth- 
er with significantly decreased cell volumes, this suggests that the inhibitory effect of neonatal SRIH-14 treatment persists in peripubertal females. In the pituitaries of adult females neonatally treated with SRIH14, the ACTH cells appeared to be much more similar to those in the controls, i.e. their cytoplasm was uniformly stained. The ACTH cell volume was however, still significantly lower than that in the corresponding controls. We have observed that the volume of ACTH cells, in the pituitaries of control females, increased from juvenile till adult period of life. The same pattern was seen in the pituitaries of treated females. It must be noted that although decreases in volume density, that is, the percentage of ACTH cells in a volume unit of total pituitary gland tissue did not reach statistical significance in peripubertal and adult SRIH-14 treated females, values tended to be lower than in the corresponding controls.

On the basis of our results we conclude that SRIH14 , applied in the neonatal period of life, exerts prolonged inhibitory effects on immunocytochemical and morphologic features of pituitary ACTH cells in female rats. Changes inflicted in the neonatal period remained until adulthood.

Acknowledgments: This work was supported by the Ministry of Science, Republic of Serbia (Grant No. 143007B).

\section{References}

[ 1] Brazeau P, Vale W, Burgus R, Ling N, Butcher M, Rivier J, Guillemin R. Hypothalamic polypeptide that inhibits the secretion of immunoreactive pituitary growth hormone. Science 1973;179:77-79.

[2] Milošević V, Sekulić M, Brkić B, Lovren M, Starčević V. Effect of centrally administered somatostatin on pituitary thyreotropes in male rats. Histochem J. 2000;32:565-569.

[3] Milošević V, Brkić B, Velkovski SD, Sekulić M, Lovren M, Starcević V, Severs WB. Morphometric and functional changes of rat pituitary somatotropes and lactotropes after central administration of somatostatin. Pharmacology 1998; 57:28-34.

[4] Starčević V, Milošević V, Brkić B, Severs W. Effects of somatostatin on morphology and secretion of pituitary LH cells in male rats. Life Sci. 2002;70:1-9.

[ 5] Nestorović N, Manojlović-Stojanoski M, Ristić N, Sekulić M, Šosić-Jurjević B, Filipović B, Milosević V. Somatostatin-14 influences pituitary-ovarian axis in peripubertal rats. Histochem Cell Biol. 2008;130:699-708.

[6] Reichlin S. Somatostatin. N Engl J Med. 1983;309:1495$1501 ; 1556-1563$.

[7] Patel YC. Somatostatin and its receptor family. Front Neuroendocrinol. 1999;20:157-198.

[ 8] Epelbaum J, Dournaud P, Fodor M, Viollet C. The neurobiology of somatostatin. Crit Rev Neurobiol. 1994;8:25-44.

[9] Maširević-Drašković G, Terzić M, Nešić D, Stevanović D, Milošević V, Starčević V, Severs WB. Effects of somatostatin-14 on active avoidance behavior in female rats. Arch Biol Sci. 2007;59:55P-56P.

[10] Stratakis C, Chrousos G. Hypothalamic hormones. In: Conn P. M., Melmed S, ed. Endocrinology: Basic and Clinical Principles. Humana press, Totowa; 1997:185-209.
[11] Horvath E, Kovacs K. Morphology of adenohypophysial cells and pituitary adenomas. In: Imura H, ed. The Pituitary Gland. Raven Press, New York; 1994:29-62.

[12] Schmid A, Schoeffter P. Functional activity of the multiligand analog SOM230 at human recombinant somatostatin receptor subtypes supports its usefulness in neuroendocrine tumors. Neuroendocrinology 2004;80:47-50.

[13] Milošević V, Brkić B, Nestorović N, Velkoski S, Starčević V. The effects of centrally applied octreotide on the ACTH cells in female rat. Acta Vet. 2001;51:283-290.

[14] Silva AP, Schoeffter P, Weckbecker G, Bruns C, Schmid HA. Regulation of CRH-induced secretion of ACTH and corticosterone by SOM230 in rats. Eur J Endocrinol. 2005;153:7-10.

[15] Milošević V, Terzić M, Manojlović-Stojanoski M, Nestorović N, Sekulić M, Starčević V. Inhibitori effect of SRIH-14 on ACTH cells in neonatal female rats. Arch Biol. Sci. 2007;59: 13P-14P.

[16] Rebuffat P, Belloni A, Musajo F, Rocco S, Markowska A, Mazzocchi G, Nussdorfer G. Evidence that endogenous somatostatin (SRIF) exerts an inhibitory control on the function and growth of rat adrenal zona glomerulosa. The possible involvement of zona medullaris as a source of endogenous SRIF. J Steroid Biochem Mol Biol. 1994;48:353-360.

[17] Sternberger L, Hardy P, Cuculis J, Mayer H. The unlabeled antibody enzyme method of immunohistochemistry, Preparation and properties of soluble antigen-antibody complex (horseradish peroxidase-antihorseradish peroxidase) and its use in identification of spirochetes. J Histochem Cytochem. 1970;18:315-333.

[18] Weibel ER. Stereological methods: Practical Methods of Biological Morphometry, Academic Press, London; 1979:1-415.

[19] Weibel ER, Gomez DM. A principle for counting tissue structures on random sections. J Appl Physiol. 1962;17:343-348.

[20] Malendowicz L. Sex differences in adrenocortical structure and function. I. The effects of postpubertal gonadectomy and gonadal hormone replacement on nuclear volume of adrenocortical cells in the rat. Cell Tissue Res. 1974;151:525-536.

[21] Starčević V, Milošević V, Brkić B, Severs W. Effects of centrally applied somatostatin on pituitary adrenocorticotropes in female rats, Pharmacology 2000;60:203-207.

[22] Milošević V, Brkić B, Nestorović N, Velkoski S, Starčević V. The effects of centrally applied octreotide on the ACTH cells in female rat. Acta Vet. 2001;51:283-290.

[23] Luque RM, Gahete MD, Hochgeschwender U, Kineman RD. Evidence that endogenous SST inhibits ACTH and ghrelin expression by independent pathways. Am J Physiol Endocrinol Metab. 2006;291:395-403.

[24] Viollet C, Vaillend C, Videau C, Bluet-Pajot MT, Ungerer A, L'Héritier A, Kopp C, Potier B, Billard J, Schaeffer J, Smith RG, Rohrer SP, Wilkinson H, Zheng H, Epelbaum J. Involvement of sst2 somatostatin receptor in locomotor, exploratory activity and emotional reactivity in mice. Eur $J$ Neurosci. 2000; 12:3761-3770.

[25] O'Carroll AM, Krempels K. Widespread distribution of somatostatin receptor messenger ribonucleic acids in rat pituitary. Endocrinology 1995;136:5224-5227.

[26] Day R, Dong W, Panetta R, Kraicer J, Greenwood MT, Patel YC. Expression of mRNA for somatostatin receptor (sstr) types 2 and 5 in individual rat pituitary cells. A double labeling in situ hybridization analysis. Endocrinology 1995;136: 5232-5235.

[27] Mezey E, Hunyady B, Mitra S, Hayes E, Liu Q, Schaeffer J, Schonbrunn A. Cell specific expression of the sst2A and sst5 somatostatin receptors in the rat anterior pituitary. Endocrinology 1998; 139:414-419.

[28] Litvin Y, Leiser M, Fleischer N, Erlichman J. Somatostatin inhibits corticotrophin releasing factor stimulated adrenocorticotropin release, adenylate cyclase, and activation of adeno- 
sine 3'5'- monophosphate dependent protein kinase isoenzymes in AtT20 cells. Endocrinology 1986;119:737-745.

[29] Strowski M, Dashkevicz M, Parmar R, Wilkinson H, Kohler M, Schaeffer J, Blake A. Somatostatin receptor subtypes 2 and 5 inhibit corticotrophin-releasing hormone-stimulated adrenocorticotropin secretion from At-20 cells. Neuroendocrinology 2002;75:339-346.

[30] Reed DK, Korytko AI, Hipkin RW, Wehrenberg WB, Schonbrunn A, Cuttler L. Pituitary somatostatin receptor (sst)1-5 expression during rat development: age-dependent expression of sst2. Endocrinology 1999;140:4739-4744.
[31] Petraglia F, Facchinetti F, D'Ambrogio G, Volpe A, Genazzani AR. Somatostatin and oxytocin infusion inhibits the rise of plasma beta-endorphin, beta-lipotrophin and cortisol induced by insulin hypoglycaemia. Clin Endocrinol (Oxf). 1986;24: 609-616.

Submitted:12 March, 2009 Accepted after reviews: 28 July, 2009 